\title{
Perceived Ease of Use and Brand Popularity: How Surcharge Modifies Its Relationship Within SMEs Choice toward Mobile Food Service Platform during Pandemic
}

\author{
Oliandes Sondakh
}

\section{ABSTRACT}

\begin{abstract}
In 2020, due to the global pandemic, the digital transformation roadmap is forced to take a big leap to adapt to a new way of life. Despite the significant increase of digital technologies, many SMEs still struggle in technology adoption, especially smaller SMEs, which have less than 10 employees, including in Indonesia. Before the pandemic occurred, many food entrepreneurs in Indonesia were not interested in joining mobile food services. This is because many food entrepreneurs believe in the competitive advantage that their restaurants have, especially in terms of taste. They believe consumers are willing to make sacrifices to consume their food. However, since the pandemic occurred and mobility restrictions were imposed, many food entrepreneurs have started to find it difficult to sell their food and inevitably must join mobile food services to survive. This makes this research interesting, considering that most food entrepreneurs in Indonesia, especially in Surabaya, are old players with old fashion ways of business. Previous research shows that perceived ease of use and brand popularity are factors that dominantly influence user decisions in using a platform. This study aims to determine the effect of perceived ease of use and brand popularity on SMEs choice toward mobile food service platforms during a pandemic, and the moderating effect of surcharge on the relationship. The results of the study show that both perceived ease of use and brand popularity has a significant effect on SMEs choice toward mobile food service platform. Interesting result was found on the moderating effect. Surcharge was found to significantly weaken the relationship between perceived ease of use and SMEs choice toward mobile food service platforms, but not significantly in the relationship between brand popularity and SMEs choice toward mobile food service platforms. Further research can be done in a different area to gain deeper and boarder perspective.
\end{abstract}

Keywords: Brand Popularity, Mobile Food Service Platform, Perceived Ease of Use, SMEs, Strategic Decision Making.

\section{INTRODUCTION}

In 2020, with the global pandemic, the digital transformation roadmap will need to make a big leap to adapt to new lifestyles. Regardless of the industry in which they do business, economic agents need to act swiftly to find ways to interact with their customers (consumers, students, workers, etc.). As pandemics change the global environment rapidly, companies of all sizes and industries are forced to equip their businesses with digital tools. Digital tools bring many important benefits to businesses. Reduce transaction costs by providing better and faster access to information, communications, and networks. It helps Small and Medium Sized Enterprises (SMEs) integrate into a wider market, by reducing costs and significantly increasing the scope of trade services. It also supports innovation, and greater access to innovation assets, as well as the potential for companies to generate data and analyze their own operations in new ways, to drive better performance.
Submitted : January 21, 2022

Published : February 22, 2022

ISSN: $2507-1076$

DOI: $10.24018 /$ ejbmr.2022.7.1.1276

Oliandes Sondakh*

Universitas Pelita Harapan, Surabaya, Indonesia.

(e-mail: oliandes.sondakh@ uph.edu)

*Corresponding Author
Despite the significant increase of digital technologies, many SMEs still struggle in technology adoption, especially smaller SMEs, which have less than 10 employees. The digital adoption gap of small SMEs compared to large companies and has grown over the last decade. That is why "Digital Recovery", which is considered a top priority in the wider context, is very important for SMEs. With diverse access to technology, SMEs have varying degrees of exposure to digital transformation, and this has become a challenge that must be faced by SME.

The COVID-19 crisis has had a negative impact on the SME sector which is unable to adapt to the changes that occur, with many companies tending to lose tens of percent of their turnover. The difference is highlighted in SMEs that could adapt to changing business conditions. Those SMEs can increase their turnover by tens or even hundreds of percent. This fact came with a clear understanding that without a comprehensive strategy that encourages SMEs to implement digital technology more consistently, the economic recovery will not be sustainable. The situation is 
worse in developing countries with market economies, where the availability of government resources to help small businesses are limited. Speed is critical to providing the support they need in the event of a crisis. Therefore, the use of digital technology has proven to be crucial in supporting small businesses in these unprecedented times. The main obstacle is the lack of knowledge about how to use the digital tools available in related business activities. These include poor financial and business literacy, limited internet use and connectivity, unreliable (corporate) identity systems, unfamiliar modern regulatory frameworks, poor data protection, and cybersecurity risks. Unlike large companies, SMEs do not have the opportunity to hire professionals to implement and guarantee the use of digital tools. In most cases, SMEs cannot provide the financial resources and resources for digitalization. Therefore, the existence of an online shopping platform that can be a place for SMEs to register and sell their products online has contributed significantly to the SMEs' digitalization process. With an outof-the-box platform provided by your e-service provider, SMEs do not have to worry about building the system itself.

Prior to the pandemic, many Indonesian food operators were not interested in participating in mobile food services. This is because many food companies believe in the competitive advantage of restaurants, especially when it comes to taste. They believe that consumers are willing to make sacrifices to consume their food. However, due to pandemics and mobility restrictions, many food businesses have difficulty selling food and inevitably need to participate in mobile food services to survive. This makes this study interesting given that most food entrepreneurs in Indonesia, especially Surabaya, are old-fashioned players who have oldfashioned ways of doing business.

According to a study conducted by Doshi (2018), ecommerce services are easy to use in the form of websites and applications, so the perceived ease of use is positively correlated with e-commerce services. The users are relieved because they know how to operate it. Once the users understand and master it, they have the flexibility to interact with it. According to a study conducted by Surendran (2012), perceived ease of use is widely used to understand and explain user behavior in information systems. The ease of use of information systems affects how users use the system. Users gain power over service providers through "access to information, access to more choices, easier transactions, increased communication between customers, general distrust and resentment between customers" (Urban, 2003, Matzler et al., 2006).

SMEs, on the other hand, typically decide to join an eservice provider purely based on their market popularity. Brand popularity can be defined as the extent to which a brand is widely purchased by the public (Kim \& Chung, 1997). Operationally, this is often defined as a description of a product's market share (Hellofs \& Jacobson, 1999). Consumers tend to believe that more buyers will show higher product quality as manufacturers are forced to consider product feedback from many customers (Liebowitz \& Margolis, 1994). In connection with online purchase decisions, consumers perceive greater risks in making online purchase decisions than offline (Tucker \& Zhang, 2011). Therefore, more information is needed to mitigate risk, and therefore both extrinsic and intrinsic clues to brand awareness are used (Richardson et al., 1994). Previous research has shown that popularity can be one of the determinants of buyer decisions in the context of online shopping.

Surcharge plays an important role in purchasing decisions in the service sector (Hanif et al., 2010). Fairness of surcharge is measured by whether the price of a product or service is reasonable and justified (Kukar Kinney et al., 2007; Xia et $a l ., 2004)$. It is not easy to measure how high a reasonable surcharge is. In this study, a surcharge is defined as a perception of how clear and clear the charges of online shopping service providers are.

\section{REVIEW OF LITERATURE}

\section{A. Strategic Decision Making}

In homes, schools, political and governmental institutions, corporate boardrooms, and executive offices, decisionmaking is a regular occurrence. Leaders and managers at the top of the organizational hierarchy make decisions, particularly strategic decisions (Wilson et al., 1986). The process by which managers identify and strive to resolve organizational problems is known as decision-making (Bartol and Martin, 1994). Strategic decision-making is an attempt to plan for an organization's long-term future to maximize the likelihood of success. Strategic decision-making is a sort of decision-making that has a significant impact on actions. The essence of strategic decisions, according to Mintzberg et al. (1976), is: A strategic decision process is distinguished by its novelty, complexity, and open-endedness, as the organization typically begins with little understanding of the decision situation it faces or the path to its solution, as well as only a hazy idea of what that solution might be and how it will be evaluated when it is developed.

\section{B. Perceived Ease of Use}

Perception is the process of an individual gaining a personal understanding of objects, phenomena, and events through observation, experience, and supervision received using the five senses. Perception is defined as the process by which a person recognizes, compares, categorizes, and interprets an object that he or she sees or experiences. Perceived ease of use, according to Monisa (2012), is the degree to which someone believes that using technology involves little effort. When it comes to technology, ease means that it is not difficult to use or that it does not need a lot of work. Individuals' perceptions of how easy this technology is to use relate to their view that information technology systems can make their tasks easier with little effort. The degree to which someone believes that adopting a certain system can improve the performance of his or her work is defined as perceived ease of use (Redzuan et al., 2016). In the context of an organization, a system with high perceived ease of use is one that users believe will be beneficial.

\section{Brand Popularity}

Brands are defined as names, terms, symbols, symbols, designs, or combinations thereof that are intended to identify products and distinguish them from competitors (Combe, 2006; Kotler \& Keller, 2009). Building a strong brand is a 
complex task (Abidin et al., 2014), as brands are an important factor in building relationships between businesses and consumers (Kotler \& Keller, 2009). Products with strong brands are easier to win the competition (Rangkuti, 2009).

\section{Surcharge}

Surcharge can be described as the nominal value charged to the consumer to acquire things and to benefit from the ownership or usage of those products in their most basic form (Kotler and Armstrong, 2009). Furthermore, a surcharge might be a hint of a product's quality (Zeithaml, 1988). Surcharges can also help with branding and distinctiveness (Nagle and Holden, 1995). Customers usually have a pricing range that they can accept. They will not want to buy a product if the price is too high, and they will question the product's quality if the price is too low (Cooper, 1969, in Dodds et al., 1991). Decision-makers must grasp the overall issue while also performing as accurate computations as possible when selecting which plan is optimal and may be adopted (Nagle and Holden, 1995).

\section{E. Hypotheses}

Perceived ease of use is a perception about how people make decisions when utilizing technology. The extent to which a person believes that employing information technology can help him or her complete his or her work/tasks is determined by his or her assessment of its ease of use. The user's behavior will be influenced by this perception. Brand popularity is a psychological state in which one party is willing to accept vulnerability because he has high hopes for the intentions of others and is willing to rely on them. Brand Popularity could lower non-monetary transaction costs, such as reducing the work and time required by customers to select an online seller. Surcharges are also likely to have an impact on purchase intent. A high surcharge will result in higher prices for the customer, reducing their propensity to choose the goods.

H1: Perceived Ease of Use significantly affect SMEs Choice toward Mobile Food Service Platform.

H2: Brand Popularity significantly affect SMEs Choice toward Mobile Food Service Platform.

H3: Surcharge significantly weaken the relationship between Perceived Ease of Use and SMEs Choice toward Mobile Food Service Platform.

H4: Surcharge significantly weaken the relationship between Brand Popularity and SMEs Choice toward Mobile Food Service Platform.

\section{Methodology}

Quantitative research, as defined by the quantitative paradigm, is the study of behavioral problems based on theoretical testing of variables, which are measured in numbers and examined using statistical processes to see if theory predictions are generalizable. Because the primary data in this study was a questionnaire, the research design was cross-sectional with a low level of intervention. The perceptions of respondents are measured and determined using five Likert scales. Using non-probability sampling with a purposeful sampling strategy to ensure that respondents are suitable for the study aims.
Because it can assess the relationship between the independent and dependent variables, linear regression and moderated regression analysis are employed to test the hypothesis. Multiple linear regression is a statistical technique for determining the impact of several independent factors on a single dependent variable. However, other variables, including the moderating variable, may have an impact on the link between the independent and dependent variables.

The relationship between the independent and dependent variables can be strengthened or weakened by this moderating variable. Depending on the moderating variable, the nature or direction of the link between the independent variables and the dependent variables might be positive or negative. Moderated Regression Analysis is a type of linear multiple regression that includes an interaction element in the regression equation (multiplication of two or more independent variables). The direction of the association between the independent and dependent variables was determined in this study using the independent variable regression coefficient (Beta); Beta $>0$ indicates a positive link. T-sig represents the significant level of the association at the 95 percent confidence level, and t-sig 0.05 denotes the level of acceptance of the hypothesis.

The study contains the independent variables namely: Perceived Ease of Use and Brand Popularity; dependent variable: SMEs Choice toward Mobile Food Service Platform; and moderating variable: Surcharge. Questionnaires were used in this study to track the effects of independent variables. It allowed for a thorough examination of respondent expectations and requirements. Questionnaires are based on likert scale: A) Strongly disagree, B) Disagree, C) Neutral, D) Agree and E) Strongly agree. $A=1, B=2, C=3$, $\mathrm{D}=4, \mathrm{E}=5$.

\section{RESULT}

Based on Table I, the value of $\mathrm{R}$ is 0.750 . This explains that there is a high correlation between Perceived Ease of Use, Brand Popularity, and SMEs Choice toward Mobile Food Service Platform. The value of Adj R2 shows that 55.4\% of SMEs Choice toward Mobile Food Service Platform can be explained through Perceived Ease of Use and Brand Popularity while the remaining $55.4 \%$ can be explained through other variables, which are not included in this study. The results of the F test show a significance value of 0.000 , which means that the research model that aims to test the effect of Perceived Ease of Use and Brand Popularity on SMEs Choice toward Mobile Food Service Platform is acceptable. Based on Table I, the following equation can be generated:

$$
\begin{gathered}
\mathrm{Y}=\mathrm{b} 1 . \mathrm{X} 1+\mathrm{b} 2 . \mathrm{X} 2 \\
\mathrm{Y}=0.584 \mathrm{X} 1+0.330 \mathrm{X} 2
\end{gathered}
$$

where:

$\mathrm{Y}=$ SMEs Choice toward Mobile Food Service Platform; $\mathrm{X} 1$ = Perceived Ease of Use;

$\mathrm{X} 2$ = Brand Popularity;

b1,2 = coefficients. 


\begin{tabular}{|c|c|c|c|c|c|c|}
\hline Model / Variable & $\mathrm{R}$ & $\mathrm{R}^{2} / \operatorname{Adj}^{2}$ & $\mathrm{~F}_{\mathrm{sig}}$ & $\begin{array}{c}\text { Standardized } \\
\text { Coefficients } \\
\text { Beta } \\
\end{array}$ & $\mathrm{t}_{\text {sig }}$ & Hypothesis \\
\hline $\begin{array}{l}\text { Perceived Ease of Use, Brand } \\
\text { Popularity* SMEs Choice toward } \\
\text { Online Shopping Application }\end{array}$ & 0.750 & 0.554 & 0 & & & \\
\hline Perceived Ease of Use & & & & 0.584 & 0.00 & Accepted \\
\hline Brand Popularity & & & & 0.330 & 0.00 & Accepted \\
\hline
\end{tabular}

The t-test was used to determine whether there was a significant effect between the independent variables partially on the dependent variable. The results of the t-test with a significance value below 0.05 indicate that the hypothesis can be accepted, whereas if the value is above 0.05 it indicates that the hypothesis is rejected. From the results of the t-test carried out, it can be concluded:

1. Perceived Ease of Use has a significant effect on SMEs Choice toward Mobile Food Service Platform.

2. Brand Popularity has a significant effect on SMEs Choice of Mobile Food Service Platform.

Based on the results of Multiple Linear Regression, then process continued by conducting Moderated Regression Analysis.

TABLE II: MULTIPLE LINEAR REGRESSION RESULT

\begin{tabular}{cccccc} 
Model & $\begin{array}{c}\text { Standardized } \\
\text { Coefficients } \\
\text { Beta }\end{array}$ & $\mathrm{t}$ & Sig. & F & Sig. \\
\hline $\begin{array}{c}\text { 1. (Dependent: SMEs } \\
\text { Choice toward Online }\end{array}$ & & & & 55.895 & 0.000 \\
$\begin{array}{c}\text { Shopping Application) } \\
\text { Perceived Ease of Use }\end{array}$ & 3.666 & 5.497 & 0.000 & & \\
$\quad$ Surcharge & 3.362 & 5.062 & 0.000 & & \\
$\quad$ Moderator & -5.076 & -4.65 & 0.000 & & \\
2. (Dependent: SMEs & & & & & \\
Choice toward Online & & & & 18.724 & 0.000 \\
Shopping Application) & 1.887 & 2.301 & 0.023 & & \\
Brand Popularity & 1.88 & 2.276 & 0.025 & & \\
$\quad$ Surcharge & -2.71 & -1.9 & 0.060 & & \\
Moderator & & & & & \\
\hline
\end{tabular}

Based on the results of Moderated Regression Analysis, it shows that the value of Perceived Ease of Use and Surcharge variables each obtained a significance value of 0.000 and 0.000 , which means that they have a significant effect on SMEs Choice toward Mobile Food Service Platform. While the coefficient value of the Moderator Variable (Perceived Ease of Use $x$ Surcharge) is -5.076 , the $t$-value is -4.651 and the significance is 0.000 . This means that Surcharge is significantly acting as a moderator of the relationship between Perceived Ease of Use and SMEs Choice toward Mobile Food Service Platform. The coefficient value of 5.076 (negative) means that Surcharge will significantly weaken the relationship between Perceived Ease of Use and SMEs Choice toward Mobile Food Service Platform.

Based on the results of Moderated Regression Analysis, it shows that the value of Brand Popularity and Surcharge variables each obtained a significance value of 0.023 and 0.025 , which means that they have a significant effect on SMEs Choice toward Mobile Food Service Platform. While the coefficient value of the Moderator Variable (Brand Popularity $x$ Surcharge) is -2.710 , the t-value is -1.902 and the significance is 0.060 . This means that Surcharge is not significantly acted as a moderator of the relationship between Brand Popularity and SMEs Choice toward Mobile Food Service Platform. The coefficient value of $-2,710$ (negative) means that Surcharge will weaken even though not significant the relationship between Brand Popularity and SMEs Choice toward Mobile Food Service Platform.

\section{DISCUSSION}

Research results show that Perceived Ease of Use and Brand Popularity has a significant effect on SMEs Choice toward Mobile Food Service Platform. This is because people download applications every day, but the truth is that many of them are abandoned or never even used. Choosing which application they are going to use will have an impact on the company's operations, at least for the next year. Ease of use is one factor to consider. An application that is inflexible or does not fit into the company's business model will incur unexpected costs. The flexibility of the application and the ability to adapt to customer needs will help the company succeed in reaching the market. On the other hand, it has been proven that most people are easily tempted by the ease of access and visibility of the product. That is why most people will download the popular application. Popular application not only means that the application will be easily recognized, but it is also a source of competitive advantage. This is because product ratings and customer reviews are effective sales drivers. Reading other customer reviews influences one's buying decision. People claim that they trust online reviews just as much as they trust personal recommendations. That is why positive feedback and ratings are very important for the application to thrive whereas negative ones will easily damage the reputation of the company.

The results of the study also show that Surcharge significantly weakens the relationship between Perceived Ease of Use and SMEs Choice toward Mobile Food Service Platform. This is because, although an application is easy to use when the fees charged by the service provider are too high, it can reduce interest in choosing the application since the majority of all online shopping application service providers have almost the same interface design, so it is not seen as a value that could provide an absolute advantage for the company. Different result was found in the relationship between Brand Popularity and SMEs Choice of Mobile Food Service Platform. Although Service Charge also has a negative (weakening) effect, the effect is not significant. This is because popularity is seen as an advantage, which allows company to reach a larger market, so Service Charge factor sometimes seen as part of trade off to gain market share.

\section{CONCLUSION}

This study aims to determine the effect of perceived ease of use and brand popularity on SMEs choice toward mobile food service platform during pandemic, and the moderating 
effect of surcharge on the relationship. The results of the study show that both perceived ease of use and brand popularity has a significant effect on SMEs choice toward mobile food service platform. Interesting result was found on the moderating effect. Surcharge was found to significantly weaken the relationship between perceived ease of use and SMEs choice toward mobile food service platforms, but not significantly in the relationship between brand popularity and SMEs choice toward mobile food service platforms. Further research can be done in a different area to gain a deeper and boarder perspective.

\section{ACKNOWLEDGMENT}

The author would like to thank Universitas Pelita Harapan especially Business School for their support so that this research can be carried out properly."

\section{REFERENCES}

Abidin, S. Z., Effendi, R. A. A. R. A., Ibrahim, R., \& Idris, M. Z. (2014). A Semantic Approach in Perception for Packaging in the SME's Food Industries in Malaysia: A Case Study of Malaysia Food Product Branding in United Kingdom. Procedia - Social and Behavioral Sciences, 115, 115-130.

Bartol, K. M. \& Martin, C. (1994). Management. New York: McGraw Hill. Combe, C. (2006). Introduction to e-Busienss: Management and Strategy. Oxford: Butterworth-Heinemann.

Dodds, W. B., Monroe, K. B., and Grewal, D. (1991) The Effects of Price, Brand and Store Information on Buyers' Product Evaluations. Journal of Marketing Research, 28 (3), 307-319.

Doshi, P. V. (2018). Relationship of Perceived Ease Use and Perceived Usefulness on Usage of E-commerce Site. International Journal of Academic Research and Development.

Hanif, M., Hafeez, S., \& Riaz, A. (2010). Factors Affecting Customer Satisfaction. International Research Journal of Finance and Economics, 60 (1), 44-52.

Hellofs, L. L., \& Jacobson, R. (1999). Market Share and Customers' Perception of Quality: When Can Firms Grow Their Way to Higher versus Lower Quality. Journal of Marketing, 63, 16-25.

Kim, C. K., \& Chung, J. Y. (1997). Brand Popularity, Country Image and Market Share: An Empirical Study. Journal of International Busines. Studies, 28, 361-386.

Kotler, P., \& Keller, K. L. (2009). Manajemen Pemasaran. Jakarta: Indeks. Kukar-Kinney, M., Xia, L., \& Monroe, K. B. (2007). Consumers' Perceptions of the Fairness of Price-Matching Refund Policies. Journal of Retailing, 83 (3), 325-337.

Liebowitz, S., \& Margolis, S. (1994). Network Externality: An Uncommon Tragedy. Journal of Economic Perspectives, 8, 133-150.

Matzler, K., Wurtele, A. \& Renzl, B. (2006). Dimensions of Price Satisfaction: A Study in the Retail Banking Industry. International Journal of Bank Marketing. 24 (4), 216-231.

Mintzberg, H., Raisinghani, D., \& Theoret, A. (1976), The Structure of "Unstructured" Decision Processes. Administrative Science Quarterly, 21 (2), 246-275.

Monisa, M. (2013). Persepsi Kemudahan dan Kegunaan OPAC Perpustakaan Unair (Study Deskriptif Menilai Persepsi Kemudahan dan Persepsi Kegunaan OPAC oleh Pengguna di Perpustakaan Universitas Airlangga). Jurnal Ilmu Informasi dan Perpustakaan FISIP Unair, 20 (1).

Nagle, T. T., \& Holden, R. K. (1995). The Strategy and Tacticsof Pricing. New Jersey: Prentice Hall.

Rangkuti, E. (2009). Strategi Promosi yang Kreatif dan Analisis Kasus Integrated Marketing Communication. Jakarta: Gramedia Pustaka Utama.

Redzuan, N. I. N., Razali, N. A., Muslim, N. A., \& Hanafi, W. N. W. (2016). Studying Perceived Usefulness and Perceived Ease of Use of Electronic Human Resource Management (e-HRM) with Behavior Intention. International Journal of Business, 1 (2).

Richardson, P., Dick, A., \& Jain, A. (1994). Extrinsic and Intrinsic Cue
Effects on Perceptions of Store Brand Quality. Journal of Marketing, $58,28-36$

Surendran, P. (2012). Technology Acceptance Model: A Survey of Literature. International Journal of Business and Social Research, 2 (4), 175-178.

Tucker, C., \& Zhang, J. (2011). How Does Popularity Information Affect Choices? A Field Experiment. Management Science, 57, 828-842.

Wilson, D. C., Butler, R. J., Cray, D., Hickson, D. J., \& Mallory, G. R. (1986). Breaking The Bounds Of Organization In Strategic Decision Making. Human Relations, 39 (4), 309-331.

Xia, L., Monroe, K. B., and Cox, J. L. (2004). The Price is Unfair! A Conceptual Framework of Price Fairness Perceptions. Journal of Marketing, 68 (4), 1-15.

Zeithaml, V. A. (1988). Consumer Perceptions of Price, Quality and Value: A Means-End Model and Synthesis of Evidence. Journal of Marketing 52 (3), 2-22. 